\title{
DECREASE OF SERUM CHOLESTEROL ESTER IN HAEMOLYTIC DISEASE OF THE NEWBORN
}

BY

\author{
ARNE ROTHE-MEYER, M.D. \\ Medical Officer, E.M.S.
}

and

\author{
EVELYN M. HICKMANS, M.Sc., Ph.D. \\ (From the Children's Hospital, Birmingham)
}

The conception of the pathological entity of the three manifestations of haemolytic disease of the newborn: hydrops foetalis, icterus gravis and congenital haemolytic anaemia has been confirmed by the discovery of the Rhesus factor. Moreover, this discovery has allowed us finally to abandon any sharp clinical distinction between the two latter forms of the disease. This is in accord with the fact that icterus may or may not be accompanied by anaemia, while anaemia may occur with or without previous jaundice. There are still, however, many unsolved problems, amongst which the question of liver damage is outstanding.

It has long been recognized that the jaundice occurring in haemolytic disease of the newborn cannot be explained as a pure haemolytic icterus. The severity of the jaundice, the positive Van den Bergh reaction and the pathological changes in the liver all point to a toxic injury of the liver. Furthermore, some cases are associated with 'kernikterus' or with late development of cirrhosis. Gilmour (1944) in his recent work on the morbid anatomy of 'erythroblastosis foetalis' has discussed the various hepatic changes, and presumed a toxic jaundice due to liver damage. The immunological reactions due to the $\mathrm{R}$ hesus factor which take place in the infant or foetus (reviewed by Taylor and Race, 1944) may afford a partial explanation for the toxic effect upon the liver.

It is well known that the serum cholesterol and its partition may exhibit characteristic changes in diseases of the liver. Thannhauser and Schaber (1926) reported eleven cases of parenchymatous liver disease, in which they found decrease of the ester fraction of the serum cholesterol with absolute and relative increase of the free cholesterol, whereas the total cholesterol values were within normal limits. In acute yellow atrophy the ester fraction had disappeared completely, a phenomenon they termed 'Estersturz' (ester drop). These findings were confirmed by other investigators who have been quoted by Epstein and Greenspan (1936). These authors themselves evaluated the clinical significance of the cholesterol partition in hepatic diseases by investigation of a large number of cases. Obstructive jaundice is characterized by a hypercholesterolaemia, affecting both the free and the ester fraction, which parallels the degree of hyperbilirubinaemia. In acute parenchymatous degeneration, especially toxic and infectious hepatitis, on the other hand, the values for total cholesterol are normal or slightly sub-normal and show no relationship to the bilirubin values. The outstanding change here is the lowering of the ester fraction, which mirrors the severity of the liver damage. In the severest cases the ester fraction is low or absent, and remains so until the fatal end. In less severe cases the low values rise to normal with clinical improvement, while in mild cases there is only moderate depression of the ester values. More recently, Gray (1940) has confirmed these observations and has also found that a long-standing complete absence of the esterified cholesterol is a bad prognostic sign. He emphasizes that in acute parenchymatous liver disease the changes of the cholesterol ester fraction are more frequent and marked than are changes in the serum proteins.

As a part of investigations on liver function tests in infancy, determinations have been made of serum cholesterol and its partition in a group of infants suffering from haemolytic disease of the newborn. This paper records the results and attempts to assess their significance.

Information concerning the normal values for serum cholesterol during infancy is rather scarce. Sperry (1936), using the method of Schoenheimer and Sperry (1934), found values for total cholesterol ranging from 71 to $190 \mathrm{mgm}$. per cent. with an average of $133 \mathrm{mgm}$. per cent. in babies aged four to twenty-five days. At birth, figures were considerably lower, but there was a pronounced rise during the first three to four days of life, and the level during the period four to twenty-five days was fairly constant. He found that in this age group the ester fraction made up 41 to 72 per cent. of the total cholesterol, a variation range much bigger than had been found in children over two years of 
age and in adults, who had an almost constant range of the ester fraction, limited to 70 to 75 per cent. of the total cholesterol. Physiological jaundice developed in about 30 per cent. of Sperry's group of sixty-three infants, but it neither affected the total cholesterol nor the cholesterol partition, an observation which forms a striking contrast to findings in haemolytic disease of the newborn.

No control figures are available for the method in the first three months of life, but unpublished results on eighty-two 'healthy' infants between three and twelve months of age, who came to the out-patient clinic for circumcision and minor surgical ailments, have shown values for tolal cholesterol between 98 and 230 mgm. per cent. while the variation range for the percentage of esterified cholesterol was 30 to 80 . This is a slightly wider range than Sperry's for younger infants, and in the interpretation of our findings in haemolytic disease, therefore, we have only accepted cholesterol ester values of less than 30 per cent. of the total cholesterol as significantly abnormal.

The thymol turbidity test, recently described by Maclagan (1944), was also included in the investigation. It is considered by the author to be analogous to the colloidal gold reaction but to be a more sensitive liver function test. In normal adults values up to 4 units have been found and similar amounts have been measured in fifty 'healthy' infants between three months and twelve months of age.

\section{Materials and methods}

The subjects for investigation were fifteen inpatients at the Birmingham Children's Hospital. Blood for analysis was taken from a scalp vein three or four hours after the last meal. No attempt was made to obtain the samples under fasting conditions, as the cholesterol values may be regarded as fairly independent of alimentary fluctuations (Heymann and Rack, 1943).

Determination of cholesterol. EXTRACTION. Lipoids were extracted from the serum by slowly running $1 \mathrm{c.cm}$. into approximately $15 \mathrm{c.cm}$. alcoholether mixture $(3: 1)$ after the method of Bloor (1929). This mixture was heated with rotation in hot water, cooled and then filtered, the precipitate being washed with alcohol-ether and the filtrate made up to $25 \mathrm{c} . \mathrm{cm}$.

TOTAL CHOLESTEROL. $2 \mathrm{c} . \mathrm{cm}$. of the filtrate were measured directly into the macro-colorimeter tube of the Evelyn colorimeter (1936), evaporated to dryness and redissolved in approximately $5 \mathrm{c.cm}$. chloroform. The Liebermann colour reaction was developed by adding $2 \mathrm{c.cm}$. acetic anhydride and $0 \cdot 2 \mathrm{c} . \mathrm{cm}$. concentrated sulphuric acid, and the final volume made to $10 \mathrm{c.cm}$. with chloroform. The maximum reading on the colorimeter galvanometer was taken (usually about ten minutes after mixing), using filter 660 , and values determined from a standard curve previously prepared from known amounts of cholesterol in the same way. The quantities here cited usually gave galvanometer readings between 50 and 70 .

FreE CHOLESTEROL. The classical method of precipitation by digitonin followed by Bloor's method (1929) of oxidation with silver dichromate was used with some modifications here described in detail. $10 \mathrm{c.cm}$. of the alcohol-ether extract were evaporated to dryness in a graduated centrifuge tube and the residue re-extracted with petroleum ether. After centrifugation the petroleum ether fraction was transferred to another centrifuge tube and concentrated to about $1 \mathrm{c.cm}$. over a steam bath. The phospholipids were then precipitated with acetone and magnesium chloride in the usual way. The acetone supernatant liquid was transferred to another centrifuge tube and evaporated to approximately $6 \mathrm{c.cm}$. Then $1 \mathrm{c.cm}$. of a saturated solution of digitonin in alcohol was added and the mixture allowed to stand for an hour or so. After evaporation to dryness the residue was washed with ether without disturbing the solid. After removing the ether by centrifugation and decanting, $2 \mathrm{c.cm}$. water were added to the residue and allowed to stand for some time (preferably overnight) to ensure complete solution. Subsequently 6 to $7 \mathrm{c.cm}$. acetone were added and after stirring well it was centrifuged and decanted. The residue was washed successively with (1) acetone, (2) acetone +ether and (3) ether, stirring well each time. The final washed precipitate was dissolved in methanol, transferred to the oxidation flask, and after removing the methanol, the residue was treated with silver dichromate as described by Bloor (1928).

Determination of serum proteins. A micro method, involving nitrogen determination by Kjeldahl digestion and photometric estimation after Nesslerization was used.

Determination of bilirubin. At the beginning of the investigation Van den Bergh's method giving results in units was used, but later, a quantitative micro-method, combining details from Malloy and Evelyn (1937) and from Haslewood and King's (1937) methods giving results in mgm. per cent. was substituted. As the values for serum proteins and bilirubin are only given for the sake of completing the clinical notes, the methods employed are not described in detail.

The thymol turbidity test. Maclagan's method was used without modification.

\section{Results}

Among the fifteen patients listed in the table, cases 3,5 and 11 are examples of icterus gravis without anaemia, while cases 8,13 and 15 represent anaemias without jaundice. The others enter an intermediate classification suffering from both icterus and anaemia. The $\mathrm{Rh}$ factor in mother and child was of the typical combination except in case 5 which represents a rare $R h$ intergroup immunisation. Anti-Rh agglutinins were found in all mothers with the exception of case 4 . (The $R h$ investigations were done by Dr. H. S. Baar, pathologist to the Children's Hospital.)

The jaundice, when present, was of varying degree and duration, but was usually of sufficient severity to imply a diagnosis of haemolytic disease of the newborn on admission. The cases of anaemia showed the typical haemolytic picture with pronounced reduction of haemoglobin and red cell counts frequently associated with 'peripheral erythroblastosis.' The only exception is case 15, which at the time of the first examination presented a hypoplastic anaemia, and in spite of repeated transfusions this persisted during the first seven months of the patient's life. As the first cholesterol 
TABLE 1

\section{SUMMARY OF FIFTEEN CASES INVESTIGATED}

\begin{tabular}{|c|c|c|c|c|c|c|c|c|c|c|}
\hline \multirow{2}{*}{ Clinical data } & \multirow{2}{*}{$\begin{array}{l}\text { Age } \\
\text { in } \\
\text { days }\end{array}$} & \multicolumn{3}{|c|}{$\begin{array}{l}\text { Cholesterol: } \\
\text { mgm. per cent. }\end{array}$} & \multicolumn{3}{|c|}{$\begin{array}{l}\text { Protein: } \\
\text { gm. per cent. }\end{array}$} & \multirow{2}{*}{$\begin{array}{l}\text { Thy- } \\
\text { mol } \\
\text { Test }\end{array}$} & \multicolumn{2}{|c|}{ Bilirubin: } \\
\hline & & Total & Ester & Free & Total & Alb. & Glob. & & Direct & Total \\
\hline 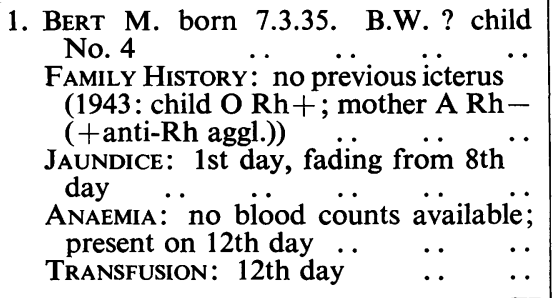 & $\begin{array}{r}1 \\
5 \\
6 \\
8 \\
11\end{array}$ & 91 & 10 & 81 & & & & & $\begin{array}{l}+ \\
+ \\
+ \\
+\end{array}$ & $\begin{array}{l}3 \text { units } \\
9 \text { units } \\
6 \cdot 5 \text { units } \\
2 \text { units }\end{array}$ \\
\hline 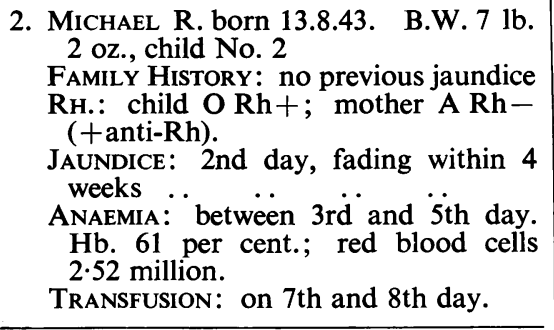 & 21 & 176 & 14 & 162 & & & & & + & $12 \cdot 8$ units \\
\hline $\begin{array}{l}\text { 3. BABY }\left({ }^{\star}\right) \text { W. born } 4.1 .45 . \text { B.W. } 6 \frac{3}{4} \mathrm{lb} . \\
\text { child No. } 3 \\
\text { FAMILY HISTORY: No } 2 \text { survived icterus } \\
\text { gravis. } \\
\text { RH.: child A Rh }+ \text {, mother A Rh- } \\
\text { (+anti-Rh). } \\
\text { JAUNDICE: 1st day, fading within } 12 \\
\text { days. } \\
\text { No ANAEMIA: for } 25 \text { days, then infec- } \\
\text { tion-anaemia, recurrent jaundice. } \\
\text { Anaemia improves after. } \\
\text { TRANSFusION: 30th day, but septic con- } \\
\text { dition aggravates. } \\
\text { DIED 35th day. AuToPsY: icterus } \\
\text { gravis, incipient hepatic cirrhosis, } \\
\text { colitis with intestinal pneumatosis, } \\
\text { purulent otitis media. }\end{array}$ & 2 & 101 & 0 & 101 & 3.97 & $2 \cdot 60$ & $1 \cdot 37$ & & - & 6.7 units \\
\hline $\begin{array}{l}\text { 4. ANTHONY C. born } 21.1 .45, \text { B.W. } 7 \frac{1}{4} \mathrm{lb} \text {. } \\
\text { child No. } 2 \text {. } \\
\text { FAMILY HISTORY: No. } 1 \text { died from } \\
\text { icterus gravis . } \\
\text { RH.: child A Rh+, mother O Rh }- \text {, } \\
\text { father A Rh+. } \\
\text { JAUNDICE: 2nd day, fading within } 3 \\
\text { weeks .. } \\
\text { ANAEMIA: on } 2 \text { nd day, Hb. } 50 \text { per cent., } \\
\text { red blood cells } 2 \cdot 20 \text { million. } \\
\text { TRANSFUSION: 2nd and } 12 \text { th day. }\end{array}$ & 40 & 120 & 88 & 126 & $4 \cdot 43$ & $2 \cdot 64$ & 1.04 & $<1$ & + & $\begin{array}{l}\text { per cent. } \\
12 \text { mgm. }\end{array}$ \\
\hline $\begin{array}{l}\text { 5. KENNETH S. born 18.1.45, B.W. } 7 \frac{1}{2} \mathrm{lb} . \text {, } \\
\text { child No. } 2 \text {. } \\
\text { FAMILY HISTORY: no previous icterus } \\
\text { RH: Child O Rh, rh (+Race Wiener } \\
\text { anti-body), father O Rh, rh, mother } \\
\text { O Rh, rh (+anti-Rh aggl.). } \\
\text { JAUNDICE: at birth, increasing several } \\
\text { days, lasted over } 4 \text { weeks .. } \\
\text { No ANAEMIA-NO TRANSFUSION. } \\
\text { KERNIKTFRUS developed. }\end{array}$ & 29 & 123 & 22 & 123 & $4 \cdot 59$ & $2 \cdot 99$ & $1 \cdot 60$ & 1 & + & $11 \mathrm{mgm}$. \\
\hline $\begin{array}{l}\text { 6. RAYMOND H. born } 10.2 .45 \text {, B.W. } 6 \frac{1}{2} \mathrm{lb} \text {. } \\
\text { Twin, No. } 3 \text { or } 4 \text {. } \because \ddot{\text { icterus. }} \\
\text { FAMILY HISTORY: no previous }\end{array}$ & 5 & 151 & 6 & 145 & $5 \cdot 32$ & 3.01 & $2 \cdot 31$ & 0 & + & 45 mgm. \\
\hline
\end{tabular}


TABLE I-continued

\begin{tabular}{|c|c|c|c|c|c|c|c|c|c|c|}
\hline \multirow{2}{*}{ Clinical data } & \multirow{2}{*}{$\begin{array}{l}\text { Age } \\
\text { in } \\
\text { days }\end{array}$} & \multicolumn{3}{|c|}{$\begin{array}{l}\text { Cholesterol: } \\
\text { mgm. per cent. }\end{array}$} & \multicolumn{3}{|c|}{$\begin{array}{l}\text { Protein: } \\
\text { gm. per cent. }\end{array}$} & \multirow{2}{*}{$\begin{array}{l}\text { Thy- } \\
\text { mol } \\
\text { Test }\end{array}$} & \multicolumn{2}{|r|}{ Bilirubin: } \\
\hline & & Total & Ester & Free & Total & Alb. & Glob. & & Direct & Total \\
\hline $\begin{array}{l}\text { RH: child O Rh }+ \text {, mother A Rh- }(+ \\
\text { anti-Rh) } \\
\text { JAUNDICE: 2nd day, fading after } \because \\
\text { weeks. } \\
\text { ANAEMIA: within } 18 \text { days, Hb. } 61 \text { per } \\
\text { cent., red blood cells } 3.50 \text { million } . . \\
\text { TRANSFUSION: } 18 \text { th and } 55 \text { th day. }\end{array}$ & 44 & 165 & 80 & 91 & $5 \cdot 10$ & $2 \cdot 92$ & $2 \cdot 18$ & $1 \cdot 5$ & + & $\begin{array}{l}\text { per cent. } \\
18 \mathrm{mgm} \text {. } \\
6 \mathrm{mgm} \text {. }\end{array}$ \\
\hline $\begin{array}{l}\text { 7. JOHN H. born } 10.2 .45, \text { B.W. } 6 \mathrm{lb} \text {. } \\
\text { Twin, No. } 3 \text { or } 4 \text {.. } \\
\text { FAMILY HISTORY and RH FACTOR as in } \\
\text { case } 6 . \\
\text { JAUNDICE: 2nd day, fading within } 3 \\
\text { weeks . } \\
\text { ANAEMIA: 4th day, Hb. } 70 \text { per cent., } \\
\text { red blood cells, } 3.28 \text { million } \\
\text { TRANSFUSION: 4th, 23rd, and 55th day }\end{array}$ & 44 & $\begin{array}{r}97 \\
110\end{array}$ & 38 & 125 & $\begin{array}{l}4 \cdot 50 \\
4 \cdot 50\end{array}$ & $\begin{array}{l}2 \cdot 84 \\
2 \cdot 84\end{array}$ & $\begin{array}{l}1.66 \\
1.66\end{array}$ & $<1$ & $\begin{array}{l}+ \\
-\end{array}$ & $\begin{array}{l}28 \mathrm{mgm} \text {. } \\
5.8 \mathrm{mgm} \text {. } \\
0.9 \mathrm{mgm} \text {. }\end{array}$ \\
\hline $\begin{array}{l}\text { 8. DAVID C. born } 24.12 .44, \text { B.W. } 7 \mathrm{lb} \text {. } \\
\text { Child No. 3. } \\
\text { FAMILY HISTORY: no previous icterus. } \\
\text { RH: child A Rh }+ \text {, mother O Rh }- \\
\text { (+anti-Rh) . } \ldots \\
\text { No CLINICAL JAUNDICE. } \\
\text { ANAEMIA: 38th day, Hb. } 28 \text { per cent., } \\
\text { red blood cells } 1.38 \text { million } . . \\
\text { TRANSFUSION: } 38 \text { th day. }\end{array}$ & 54 & 139 & 39 & 102 & $\begin{array}{l}4 \cdot 07 \\
4 \cdot 44\end{array}$ & $3 \cdot 19$ & $2 \cdot 13$ & 1 & - & $\begin{array}{l}1.3 \mathrm{mgm} \text {. } \\
0.65 \mathrm{mgm} \text {. }\end{array}$ \\
\hline $\begin{array}{l}\text { 9. RoNALD E. born 19.1.45. B.W. } 5 \text { lb., } \\
\text { child No. } 3 \text {. . } 2 \text { died from } \\
\text { FAMILY HISTORY: No. } 2 \text { dice at } 2 \text { days old. } \\
\text { jaundice } \\
\text { RH: child O Rh }+ \text {, mother O Rh- } \\
\text { (+anti-Rh). } \\
\text { JAUNDICE: 1st day, fading after } 1 \text { week. } \\
\text { ANAEMIA: 4th day, Hb. } 55 \text { per cent., } \\
\text { red blood cells } 2.37 \text { million. } \\
\text { TRANSFUSION: 6th and 15th day. }\end{array}$ & 5 & 148 & 45 & 103 & $4 \cdot 75$ & & $1 \cdot 0$ & 1 & + & 20 mgm. \\
\hline $\begin{array}{l}\text { 10. CAROLE D. born } 6.3 .45, \text { B.W. } 7 \mathrm{lb} \text {., } \\
\text { child No. } 2 \text {. } \\
\text { FAMILY HISTORY: no previous icterus } \\
\text { RH: child A Rh }+ \text {, mother A Rh- } \\
\text { (+anti-Rh). } \\
\text { JAUNDICE: at birth, fading within } 2 \\
\text { weeks. } \\
\text { ANAEMIA: 16th day, Hb. } 48 \text { per cent., } \\
\text { red blood cells } 1.97 \text { million. } \\
\text { TRANSFUSION: 16th day. }\end{array}$ & 16 & 86 & 39 & 47 & $5 \cdot 31$ & $3 \cdot 50$ & $1 \cdot 81$ & 1 & - & $2.4 \mathrm{mgm}$. \\
\hline $\begin{array}{l}\text { 11. JOHN O'K. born } 4.12 .44, \text { B.W. } 6 \frac{3}{4} \mathrm{lb} \text {., } \\
\text { child No. } 2 \text {. } \\
\text { FAMILY HISTORY: no previous icterus } \\
\text { RH: child O Rh }+ \text {, mother O Rh - } \\
\text { ( }+ \text { anti-Rh). } \\
\text { JAUNDICE: 3rd day, fading within } 3 \\
\text { weeks. } \\
\text { NO ANAEMIA-NO TRANSFUSION. }\end{array}$ & 14 & 166 & 87 & 79 & $5 \cdot 18$ & $3 \cdot 69$ & $1 \cdot 49$ & & - & 2 units \\
\hline $\begin{array}{l}\text { 12. MiCHAEL H. born } 15.11 .44 \text {, B.W. } 5 \frac{3}{4} \mathrm{lb} \text {., } \\
\text { child No. } 3 \text {. } \\
\text { FAMILY HISTORY: no previous icterus } \\
\text { RH: child O Rh }+ \text {, mother A Rh- } \\
\text { (+anti-Rh). } \\
\text { JAUNDICE: 1st day, fading within } 2 \\
\text { weeks. } \\
\text { ANAEMIA: between 5th and } 12 \text { th day, } \\
\text { Hb. } 60 \text { per cent., red blood cells } 2 \cdot 23 \\
\text { million. } \\
\text { TRANSFUSION: } 16 \text { th and 44th day. }\end{array}$ & 7 & 103 & 55 & 48 & $4 \cdot 70$ & $2 \cdot 41$ & $2 \cdot 29$ & & & \\
\hline
\end{tabular}


TABLE I-continued

\begin{tabular}{|c|c|c|c|c|c|c|c|c|c|c|}
\hline \multirow{2}{*}{ Clinical data } & \multirow{2}{*}{$\begin{array}{l}\text { Age } \\
\text { in } \\
\text { days }\end{array}$} & \multicolumn{3}{|c|}{$\begin{array}{l}\text { Cholesterol: } \\
\text { mgm. per cent. }\end{array}$} & \multicolumn{3}{|c|}{$\begin{array}{l}\text { Protein: } \\
\text { gm. per cent. }\end{array}$} & \multirow{2}{*}{$\begin{array}{l}\text { Thy- } \\
\text { mol } \\
\text { test }\end{array}$} & \multicolumn{2}{|c|}{ Bilirubin: } \\
\hline & & Total & Ester & Free & Total & Alb. & Glob. & & Direct & Total \\
\hline $\begin{array}{l}\text { 13. BABY (ठ) B. born } 21.2 .45, \text { B.W. ? child } \\
\text { No. 3. } \\
\text { FAMILY HISTORY: No. } 2 \text { died from } \\
\text { icterus gravis . } . . \\
\text { RH: child A Rh }+ \text {, mother A Rh }- \\
\text { (+anti-Rh). } \\
\text { No CLINICAL JAUNDICE. } \\
\text { ANAEMIA: 7th day, Hb. } 29 \text { per cent., } \\
\text { red blood cells } 0.94 \text { million. } \\
\text { TRANSFUSION: 7th and 14th day. }\end{array}$ & 7 & 175 & 123 & 52 & $6 \cdot 25$ & $3 \cdot 78$ & $2 \cdot 47$ & $<5$ & + & $\begin{array}{l}\text { per cent. } \\
2 \cdot 7 \text { mgm. }\end{array}$ \\
\hline 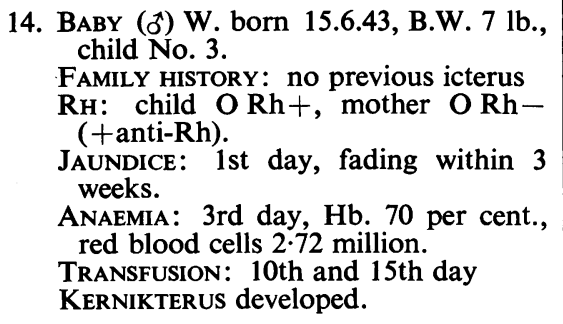 & 4 & 132 & 100 & 32 & & & & & + & 20 units \\
\hline $\begin{array}{l}\text { 15. DEREK C. born } 13.7 .44, \text { B.W. ? child } \\
\text { No. 8. } \\
\text { FAMILY HISTORY: } 1 \text { child died from } \\
\text { anaemia in infancy. } \\
\text { RH: child A Rh }+ \text {, mother A Rh- } \\
\text { (+anti-Rh). } \\
\text { No JAUNDICE OBSERVED } \\
\text { ANAEMIA: 66th day, Hb. } 32 \text { per cent., } \\
\text { red blood cells } 1 \cdot 83 \text { million. Hypo- } \\
\text { plastic anaemia persisted until age of } \\
8 \text { months. } \\
\text { TRANSFUSION: } 8 \text { transfusions between } \\
\text { 67th and 200th day of life .. }\end{array}$ & 215 & 113 & 87 & 26 & $4 \cdot 81$ & $3 \cdot 58$ & $1 \cdot 23$ & 2 & - & $\begin{array}{l}\text { per cent. } \\
0.3 \mathrm{mgm} \text {. }\end{array}$ \\
\hline
\end{tabular}

estimation was only made when the child was a hundred days old, i.e. at the time when a cholesterol ester decrease might have been compensated, this case will be excluded from the following discussion.

The remaining fourteen cases show values for total cholesterol within normal limits. Nine of these fourteen cases however, showed a marked decrease of the esterified cholesterol fraction, which in six cases (no. 1 to 6) represents 0 or less than 10 per cent. of the total cholesterol, while three cases (no. 7 to 9) render values between 20 per cent. and 30 per cent. of the total cholesterol.

The cholesterol ester decrease may be present on the first day of life (case 1) and has, in untreated cases, been found present as late as the twentyninth and thirty-ninth day (cases 15 and 8). The duration of the 'ester drop' has not yet been defined. Repeated estimations were done in five cases; the ester fraction had regained normal values on the twenty-sixth, twenty-sixth and fortieth day in cases 4,5 and 6 , while two cases still showed a marked ester decrease on the forty-ninth and fiftyfourth day (cases 5 and 8 ).

Blood transfusion does not appear to accelerate the restitution of the esterified cholesterol. Case 4 showed extreme ester decrease on the twelfth day of life in spite of previous transfusion, and in case 8 the low ester value remained unchanged from the thirty-ninth to the fifty-fourth day despite transfusion between these dates.

TABLE 2

DISTRIBUTION OF CASES IN REGARD TO JAUNDICE AND ANAEMIA

\begin{tabular}{|c|c|c|c|}
\hline & $+\begin{array}{c}\text { Cholesterol } \\
\text { change }\end{array}$ & $\begin{array}{c}\text { - Cholesterol } \\
\text { change }\end{array}$ & Tota \\
\hline $\begin{array}{l}\text { JAUNDICE WITHOUT } \\
\text { ANAEMIA.. } \\
\text { JAUNDICE PLUS } \\
\text { ANAEMIA. . } \\
\text { ANAEMIA WITHOUT } \\
\text { JAUNDICE }\end{array}$ & $\begin{array}{l}2 \\
6 \\
1\end{array}$ & $\begin{array}{l}1 \\
3 \\
1(+1)\end{array}$ & $\begin{array}{l}3 \\
9\end{array}$ \\
\hline Totals & 9 & 5 & 14 \\
\hline
\end{tabular}

No appreciable correlation between the cholesterol ester decrease and the onset, degree and duration of the jaundice or of the anaemia could be demonstrated in this investigation. It is interesting to notice that the marked 'ester drop' occurs in one case (no. 8) in which a clinical jaundice had never been observed, and in two cases (no. 3 and 5) which did not develop any anaemia. Of the two cases 
associated with kernikterus, one presented the ' ester drop' (case 5), the other did not (case 14).

The thymol turbidity test was performed in six of the nine cases with cholesterol ester changes, and in two of the five cases without such changes; it showed normal values in all these cases, the figure of 5 units in case 13 not being significant as it occurred in lipaemic serum.

\section{Conclusions}

The changes in the cholesterol partition which have been found in nine out of fourteen cases of haemolytic disease of the newborn are quite similar to those demonstrated as characteristic of acute toxic injury of the liver. No explanation can be offered for the fact that in five cases in the series no such changes were found. Admittedly these cases may have been less severe, but there does not seem to have been any essential deviation in clinical type or course to account for the difference. In this connexion it will be well to remember two points. Firstly, the typical changes reported in the literature have not been found in all cases where from the clinical aspect they might have been expected. Secondly, it is still unknown which function or dysfunction of the liver is involved when there are changes of the serum cholesterol partition.

Many questions have been left unanswered in the investigation, because the series was too small. The frequency and the duration of the cholesterol changes and also the relationship of these changes to jaundice (and possibly anaemia) have still to be settled. More information is needed concerning the morbid anatomy of the hepatic changes during the acute stages of the haemolytic disease. This may be obtained, if a procedure of intervital liver biopsy which is safe for infants can be evolved. Finally, the possibility of a correlation between the cholesterol changes and the agglutinin titre in the blood of the mothers and infants has to be investigated. It is hoped that this report will induce investigators who have the opportunity, to take up some of these problems.

\section{Summary}

The serum cholesterol partition in fouiteen cases of haemolytic disease of the newborn was determined.

The values for total cholesterol were within normal limits in all cases.

Nine of the fourteen cases showed a marked decrease or complete absence of the esterified fraction of cholesterol, findings quite similar to those demonstrated as characteristic of acute toxic liver injury.

The thymol turbidity test of Maclagan, which was performed in six of the nine cases, showed normal values.

The authors are grateful to the Honorary Staff of the Hospital for allowing them to investigate their patients, and to the Medical Research Council for defraying part of the expenses of the laboratory work, and for a grant to one of us (E. M. H.).

\section{REFERENCES}

Bloor, W. R. (1928). J. biol. Chem., 77, 53. (1929). Ibid., 82, 273.

Epstein, E. Z., and Greenspan, E. B. (1936). Arch. intern. Med., 58, 860.

Evelyn, K. A. (1936). J. biol. Chem., 115, 63.

Gilmour, J. R. (1944). Arch. Dis. Childh., 19, 1.

Gray, S. J. (1940). Arch. intern. Med., 65, 524.

Haslewood, G. A. D., and King, E. J. (1937). Biochem. $J ., 31,920$.

Heymann, W., and Rack, F. (1943). Amer. J. Dis. Child., 65, 235.

Maclagan, N. F. (1944). Nature, 154, 670.

Malloy, H. T., and Evelyn, K. A. (1937). J. biol. Chem., 119, 481 .

Schoenheimer, R., and Sperry, W. M. (1934). Ibid., 106, 745.

Sperry, W. M. (1936a). Ibid., 114, 135.

(1936b). Amer. J. Dis. Child., 51, 84.

Taylor, J. L., and Race, R. R. (1944). Brit. med. Bull., 2, 160 .

Thannhauser, S. J., and Schaber, H. (1926). Klin. Wschr., 5, 252. 